\title{
„KRYZYS MONARCHII PIASTOWSKIEJ” I PROBLEM TZW. REAKCJI POGAŃSKIEJ OKIEM ARCHEOLOGA
}

\author{
"THE CRISIS OF THE PIAST MONARCHY" AND THE ISSUE OF THE \\ SO-CALLED PAGAN BACKLASH AS VIEWED BY AN ARCHAEOLOGIST
}

\begin{abstract}
The turmoil of the 1030s in the Polish territory has so far attracted attention of historians. A detailed analysis of the information available in the written sources has strengthened a position in the result of which (in line with the reference to the events in question) the pagan backlash was to stem primarily from religious reasons. This interpretations suggests and provokes reception of Mieszko II's domain as a completely Christian organisation. Consequently, at least officially it suggests that the pagan communities had been pushed to the margins of the society. Scholars have no doubts that these communities existed because they are regarded to have affected the events of the 1030s. Was it really the case? An analysis of archaeological sources, previously not used in the discussion of the pagan backlash, does not answer the questions so unambiguously. There is a strong indication that the followers of the old values did not have to flee from persecutions or the missionary ideology. It also looks like they did not have to fear financial exploitation for the benefit of the established church structures which could have easily operated parallel to venues referring to the traditional religious symbols. If we assume that it was the case, were the events of the 1030s in fact a pagan backlash? This question was at the basis of the considerations presented in this text.
\end{abstract}

Keywords: Pagan backlash, crisis of the Piast monarchy, Mieszko II, Gniezno, Giecz.

\section{ZAGADNIENIA WSTĘPNE}

Problem wydarzeń, jakie rozegrały się w latach 30. XI wieku na ziemiach znajdujących się pod zwierzchnictwem Mieszka II, doczekał się już obszernej literatury, tworzonej głównie piórem historyków. Od dłuższego już czasu - z nielicznymi wyjątkami (o których niżej) - nie znajduje on jednak szerszego uznania wśród badaczy zajmujących się dziejami wczesnej monarchii piastowskiej.

* ORCID: 0000-0001-9538-0963, Muzeum Zachodniokaszubskie w Bytowie, ul. Zamkowa 2, 77-100 Bytów, e-mail: kamilkajkowski@wp.pl. 
Niewykluczone, że taki stan rzeczy wynika $\mathrm{z}$ ograniczonego zasobu wielokrotnie i na różne sposoby analizowanej oraz interpretowanej bazy źródeł pisanych. Warto jednak zauważyć, że w pracach dotyczących interesującego nas problemu niemal w ogóle nie próbuje się sięgać do dorobku archeologii1 ${ }^{1}$, która - jak sądzę - może całkiem nieźle wzbogacić stan wiedzy nad zagadnieniem tzw. reakcji pogańskiej. Jak wkrótce zobaczymy, obecny zasób informacji wynikających z rezultatów prac wykopaliskowych może nie tylko poszerzyć, ale także zrewidować stan dyskusji nad zajmującym nas tematem. Zanim jednak przywołamy odpowiednie źródła, które - siłą rzeczy - zostaną skonfrontowane $\mathrm{z}$ dotychczasowymi ustaleniami historyków, nieco uwagi należy poświęcić właśnie tym ostatnim. $Z$ tym jednak zastrzeżeniem, że nie będzie nas zajmować szczegółowa analiza źródeł, lecz ujęcie historiograficzne. Innymi słowy, sposób, w jaki zostały one zinterpretowane i odniesione do wiedzy na temat epoki oraz „reakcji pogańskiej”. W dalszej kolejności przyjrzymy się wiadomościom historycznym na temat przebiegu chrystianizacji ziem znajdujących się pod rządami pierwszych Piastów. Szersze ujęcie tematu, niesprowadzające się wyłącznie do sytuacji zaistniałej za rządów Mieszka II, pozwoli na bardziej kompleksowe ujęcie zagadnienia, a tym samym uniknięcie „wyrwania" niektórych problemów z kontekstu procesu przecież niezakończonego i trwającego jeszcze długo po śmierci drugiego króla Polski. W dalszym etapie badań przyjrzymy się, co na ten temat „mówią” wyniki badań wykopaliskowych i jak problem recepcji chrześcijaństwa postrzegają archeolodzy, by - sumując wiedzę wynikającą z wymowy obu rodzajów źródeł - podjąć próbę odpowiedzi na pytania, (1) czy w trakcie rządów trzech pierwszych historycznych Piastów na ziemiach stanowiących trzon formującego się państwa obserwujemy ślady konfliktu wyznaniowego, oraz (2) czy za Mieszka II doszło do wydarzeń określonych w literaturze mianem reakcji pogańskiej?

\section{REAKCJA POGAŃSKA W UJĘCIU HISTORIOGRAFII}

W latach 30. XI wieku na ziemiach znajdujących się pod bezpośrednią kontrolą administracji piastowskiej doszło do znamiennych w skutkach zaburzeń. Informacje pojawiające się w źródłach spisanych przez Anonima zwanego Gallem, Kosmasa, Anonima Minoryty, autorów rocznika z Hildesheim i „Powieści minionych lat" wskazują, że wydarzenia te (czy może raczej wyobrażenia na ich temat) musiały odbić się dość szerokim echem w ówczesnej Europie. Cechą wspólną zachowanych zapisów jest ujęcie relacjonowanych wypadków w ramy wystąpień

Co ciekawe, temat ten rzadko pozostaje w sferze zainteresowań i samych archeologów, u których jeśli się pojawiał, to marginalnie w kontekście interpretacji konkretnych znalezisk rejestrowanych na określonych stanowiskach (np. Moździoch 2000, s. 182; Chudziak 2003). 
skierowanych przeciwko chrześcijaństwu oraz strukturom kościelnym². Taki też sposób postrzegania tych wydarzeń ugruntowany został w polskiej historiografii (np. Labuda 2008, s. 90; Górczak 2000, s. 120-121). W toku rozwijającej się dyskusji, dotyczącej interpretacji zapisów źródłowych, konsekwentnie i niezmiennie znaczącą rolę przypisywano więc przede wszystkim bodźcom religijnym. W myśl nowszych ustaleń miały one jednak pozostać wtórne w stosunku do dominujących czynników społecznych czy społeczno-politycznych (por. Śliwiński 2014, s. 202).

Mimo pewnych różnic dotyczących przebiegu omawianych wypadków, w zasadzie wszystkie dotychczasowe wystąpienia badaczy podkreślają, że mogły one zaistnieć, ponieważ znalazły podatny grunt w postaci powierzchownej ewangelizacji. W związku z tym znaczne masy ludności - co istotne: plebejskiej - były albo półchrześcijanami, albo poganami (mającymi już jednak działać w głębokim - jak to ujął Gerard Labuda - podziemiu). Zarówno płytkość oficjalnej konwersji tych pierwszych, jak i przekonania drugich miały być bezpośrednim zarzewiem zrywu pogan. Same zaburzenia miałaby w tym ujęciu przebieg oddolny, co wyłączało z niej większość elit oraz mieszkańców grodów mających pozostać w stosunku lojalności do władcy - dodajmy: władcy oddanego i przekonanego do nowych normatywów religijnych (por. Śliwiński 2014, s. 235, tam dyskusja i dalsza literatura).

Jako bezpośrednią przyczynę omawianych wydarzeń przyjmuje się ambicje Bezpryma, najstarszego syna Bolesława Chrobrego, który nie objął rządów po śmierci ojca. Ambicje te, podparte autorytetem cesarstwa, ostatecznie doprowadziły do ucieczki sprawującego dotąd rządy młodszego z braci, Mieszka. To właśnie Bezprym miał się przyczynić i stanąć na czele wystąpień, których ostrze rychło skierowało się przeciwko administracji państwowej i Kościołowi (Labuda 2008, s. 90). Dlatego też, w opinii niektórych badaczy (np. Labuda 2008, s. 94), główny impuls do podjęcia buntu miał płynąć z Wielkopolski (może również Kujaw), przybierając kształt „wystąpień wyspowych w różnych miejscach”, nieobejmujących całości ziem znajdujących się pod zwierzchnictwem Piastów. Dodajmy, że wzmiankowany już, oddolny charakter owych wystąpień pozbawionych wsparcia (przekonanych do chrześcijaństwa) elit, miałby być zrywem spontanicznym i pozbawionym kierownictwa (Górczak 2000, s. 120-121; Śliwiński 2014, s. 238).

Nieco inaczej przebieg interesujących nas wydarzeń ujął Błażej Śliwiński. Historyk uznał bowiem, że wystąpienia społeczne były wynikiem polityki Bezpryma skierowanej m.in. przeciwko elitom pozostającym wiernym Mieszkowi II. W takim

2 W dyskusji zogniskowanej wokół interesującego nas problemu badacze często sięgają do źródeł dotyczących innych wydarzeń interpretowanych w kategoriach reakcji pogańskich. Problem ten nie będzie nas tutaj zajmował, każde $\mathrm{z}$ tych wydarzeń należałoby bowiem rozpatrywać indywidualnie w kontekście towarzyszącej im sytuacji społeczno-politycznej. Podzielam tutaj wątpliwości Dariusza Sikorskiego (2017, s. 216), który z jednej strony wskazuje na pewne podobieństwa między sytuacją zanotowaną w Polsce, Czechach i Skandynawii, z drugiej zaś podkreśla potrzebę innego spojrzenia na przebieg wypadków odnotowany na Połabiu oraz dyskusyjność analogii węgierskiej. 
rozumieniu to właśnie na nich spoczywać miał ciężar zainicjowania i przewodzenia rozruchom (Śliwiński 2014, s. 209).

U podstaw omawianych rozbieżności interpretacyjnych leży trudny (jeśli w ogóle możliwy) do rozwiązania problem, jakim jest określenie czasu wybuchu „reakcji pogańskiej”. Jeśli bowiem w przekazach czeskich i ruskich wybuch zamieszek datuje się na rok 1031, to już źródła rodzime i zachodnie (niemieckie) sytuują je po śmierci Mieszka II, w początkowej fazie rządów Kazimierza Odnowiciela. W obu grupach przekazów znajdujemy także zasadnicze różnice w opisie charakteru „rewolty” - pierwsze z nich mówią o zaburzeniach jako takich, drugie podkreślają prześladowanie i upadek chrześcijaństwa. Rozbieżności te doprowadziły część historyków do konkluzji, że należałoby rozważyć dwa etapy opisywanych wydarzeń, z których pierwszy był wynikiem rozgrywek między Bezprymem i Mieszkiem II, drugi zaś wybuchł po zgonie młodszego z braci w maju 1034 roku (Śliwiński 2014, s. 212, tam dalsza literatura). Jednakże większość badaczy podąża tu za ustaleniami Gerarda Labudy (2008, s. 92), który ich przebieg umieszcza w przedziale między 1031 a 1034 rokiem.

Analiza dotychczasowych propozycji interpretacyjnych wskazuje, że podstawą prowadzonej dyskusji i wysuwanych wniosków jest zarówno kwestia roli, jak i stopnia konwersji ludności zamieszkującej obszar ówczesnej Polski. Rzeczywiście jest to dla podjętych rozważań sprawa kluczowa, dlatego też musimy przyjrzeć się jej z nieco większą uwagą.

\section{CHRYSTIANIZACJA I STOPIEŃ RECEPCJI NOWEJ RELIGII W UJĘCIU ŹRÓDEŁ PISANYCH}

Truizmem jest już dzisiaj stwierdzenie, że w 966 roku doszło do chrystianizacji Polski. W opinii większości badaczy ani data roczna, ani skala zjawiska nie mają uzasadnienia w materiale źródłowym. Nie znamy też okoliczności przystąpienia Mieszka I do wspólnoty Chistianitas. Gdzie należy szukać przyczyn takiego stanu rzeczy? Dlaczego w żadnym ze znanych nam zapisów źródłowych nie odnotowano informacji na ten temat? Na te pytania, w świetle dotychczasowej wiedzy, nie jesteśmy $\mathrm{w}$ stanie udzielić przekonującej odpowiedzi i jak słusznie skonstatował Przemysław Urbańczyk, „możemy się tylko dziwić, że to fundamentalne dla naszej historii wydarzenie nie zwróciło uwagi autorów zachowanych kronik i roczników" (Urbańczyk 2016, s. 19, por. Dobosz 2017, s. 213). Informacje na ten temat pojawiają się dopiero w źródłach XI-wiecznych, jednak albo „nie umiemy [w nich odnaleźć] jakichś ziaren prawdy historycznej”, albo możemy je uznać za „historiograficzną konstrukcję własną średniowiecznego intelektualisty” (Banaszkiewicz 2014, s. 284, 263). Wszystko to dowodzi, jak mało wiedziano w czasie spisywania tych źródeł na temat przebiegu procesu chrystianizacji na ziemiach podległych Mieszkowi I. Niewiele wnoszą tu również Roczniki Jana 
Długosza (ks. II, s. 241-244), który zgromadził wszystkie obecne w ówczesnej mu tradycji historycznej wątki dotyczące początków chrześcijaństwa w Polsce, jednak w większości jest to relacja oparta na wyobrażeniach kronikarza, w której trudno doszukiwać się echa rzeczywistych wydarzeń (inaczej Wyrwa 2016, s. 38).

Zdecydowanie więcej informacji znajdujemy w przekazach dotyczących recepcji nowej wiary za czasów panowania Bolesława Chrobrego. Współczesny i niechętny mu Thietmar co prawda podkreśla zasługi Piasta w szerzeniu chrześcijaństwa, ale nie omieszkał dolać łyżki dziegciu. Kronikarz wspomina bowiem, że mimo dużego zaangażowania władcy, jego poddanych trzeba było „pilnować jak bydła i karać jak upartego osła" (Thietmar VIII, 2). Zresztą sam Chrobry daleki był, w opinii kronikarza, od ideału chrześcijańskiego władcy, hołdując poligamii, lubieżności i rozwiązłości. Innego zdania był Brunon z Kwerfurtu, który kreuje w swoich dziełach (Żywocie Pięciu Braci i Liście do Henryka II) obraz Bożego wybrańca, jednego z największych krzewicieli chrześcijaństwa swoich czasów (Śliwiński 2014, s. 115). Czyni to świadomie i wbrew rozpowszechnianej w cesarstwie opinii przypisującej Chrobremu łatkę przebiegłego gracza dbającego jedynie o własne interesy i doczesne korzyści (Brojer 2014, s. 349). Taki obraz późniejszego króla Polski był zapewne odbiciem ambicji oraz zdecydowanej i agresywnej polityki, którą - zresztą skutecznie - realizował. Aby osiągnąć sukces, władca ten nie cofał się przed środkami, które w oczach ówczesnych środowisk intelektualnych mogły odbiegać od cech określających pomazańca Bożego. Być może świadom był tego, piszący kilkadziesiąt lat po śmierci Chrobrego, Anonim zwany Gallem, przemilczając cechy niepasujące "do potrzeb propagandy dynastycznej, która umiejętnie kształtowała legendę o 'złotym wieku', jaki nastąpił pod rządami monarchy" (Urbańczyk 2017, s. 292). W ujęciu Kroniki polskiej był więc Bolesław „człowiekiem samych zalet - przykładnym chrześcijaninem i walecznym dowódcą" (Urbańczyk 2017, s. 292). Była to zatem konstrukcja literacka, wizja oparta na wyobrażeniach Galla (Michałowski 2016, s. 37) bądź „przygotowana” na potrzeby propagandy dworu piastowskiego.

Jednak i tym razem kronikarz (zapewne nieświadomie) rzuca cień na idealny obraz umacniania i rozszerzania chrześcijaństwa w Polsce. Wizerunek ten mąci opis dotyczący postaci św. Wojciecha, a konkretnie decyzji w sprawie wyprawy misyjnej do Prusów, kiedy dziejopis wskazuje na jej okoliczności. Według Galla zapadła ona bowiem po tym, jak biskup praski ,zobaczył, że w Polsce wiara już kiełkuje i święty Kościół będzie wzrastał" (Gall I, 6). I mimo że część badaczy widzi w tej decyzji kolejny etap skutecznie prowadzonej akcji misyjnej (ostatnio Węcowski 2014, s. 299), to wydaje się jednak, że jej przyczyna leżeć mogła w mizernych wynikach akcji ewangelizacyjnej prowadzonej wśród poddanych (nie tylko zresztą) Bolesława Chrobrego (podobnie już Dowiat 1961, s. 121; ostatnio Cetwiński 2016, s. 107; Sikorski 2016, s. 36; Matla 2017, s. 120).

Zbliżony obraz stosunków wyznaniowych miał charakteryzować ludność podległą kolejnemu z Piastów - Mieszkowi II. W ujęciu interesującego nas w tym 
miejscu fragmentu Kroniki polskiej miał to być „lud przewrotny i nie całkiem chrześcijański” (Gall II, 44). Co prawda Anonim wkłada te słowa w usta żony władcy - Rychezy, którą posądzano o nienawiść do Polaków i wzgardę dla słowiańskiej kultury (por. Strzelczyk 2012, s. 21), jednak - szczególnie w kontekście przyczyn misji pruskiej św. Wojciecha - taka charakterystyka nie musi mijać się z rzeczywistością.

Lektura treści zachowanych w źródłach niejednoznacznie ukazuje także postać samego króla. Jeśli bowiem w liście księżnej Matyldy podkreśla się wyjątkowe oddanie Mieszka II dla chrześcijaństwa, wynosząc jego zasługi w działalności fundacyjnej, to anonimowa kronika klasztoru w Brauweiler kreśli obraz barbarzyńcy i półpoganina niegodnego królewskiej korony (Szajnocha 1859, s. 229; Wiszewski 2008, s. 329, 464; Strzelczyk 2012, s. 21).

Dotychczasowy stan badań nad treścią przekazów pisanych dotyczących recepcji chrześcijaństwa za czasów pierwszej monarchii piastowskiej skłania do wysunięcia dwóch zasadniczych wniosków. Pierwszym z nich jest ambiwalentne ujęcie postaci władców, którzy z jednej strony mieli być przekonani i oddani zasadom nowej religii, z drugiej zaś byli ludźmi gwałtownymi, agresywnymi, a nade wszystko oddającymi się zwyczajom zakorzenionym we wcześniejszej, niechrześcijańskiej tradycji. W takim ujęciu trudno przypisywać im cechy wzoru cnót chrześcijańskich. Nie było to zresztą nic nadzwyczajnego, ówczesna sytuacja społeczno-polityczna powodowała bowiem, że władcy tych czasów takim wzorem być po prostu nie mogli ${ }^{3}$ (Urbańczyk 2017, s. 16).

Niejednoznaczny pozostaje także problem zaangażowania trzech pierwszych Piastów w akcje ewangelizacji podległej im ludności. W przekazach źródłowych czytamy bowiem zarówno o „kiełkującej w Polsce wierze” (Gall I, 6), jak i o tym, że nie znalazła ona posłuchu, a neofitów ,trzeba było pilnować jak bydła” (Thietmar VIII, 2). Musimy więc pogodzić się z faktem, że nie znajdziemy w nich jednoznacznej odpowiedzi na pytanie o rzeczywisty stan recepcji chrześcijańskiego modelu kulturowego na interesującym nas terenie. Jesteśmy jednak w o tyle dobrej sytuacji, że możemy się w tym zakresie odwołać do innego rodzaju źródeł, jakimi są wyniki badań wykopaliskowych.

\section{RECEPCJA CHRZEŚCIJAŃSTWA W ŚWIETLE ŹRÓDEŁ ARCHEOLOGICZNYCH}

Od wielu już lat archeolodzy podkreślają, że dokonujące na przełomie I i II tysiąclecia zmiany kulturowo-polityczne, jakie dotknęły ludy ówczesnego barbaricum, miały doniosłe konsekwencje w reorganizacji struktur determinujących byt tych

${ }^{3}$ Co nie zmienia faktu, że niektórzy (Włodzimierz Wielki, Stefan Wielki, Henryk II) doczekali się kanonizacji. 
społeczności. Były to zmiany, które w konsekwencji doprowadziły m.in. do powstania organizmów będących zalążkiem późniejszych państw.

Dzięki ostatnim ustaleniom dotyczącym początków państwa polskiego, z dużą dozą prawdopodobieństwa możemy stwierdzić, że - wbrew dawniejszym poglądom - nie należy ich łączyć $\mathrm{z}$ długotrwałymi procesami ewolucyjnymi zapoczątkowanymi w tzw. dobie plemiennej. Wiele wskazuje wszak na to, że były to wydarzenia o gwałtownym przebiegu (Kara 2013), a jednym z najistotniejszych wyznaczników tych procesów było powstanie grodów centralnych (sedes regni principales) stanowiących oparcie monarchii wczesnopiastowskiej. Wyniki badań wykopaliskowych wskazują jednocześnie, że były to potężnie ufortyfikowane obiekty o zróżnicowanej funkcji spełniające rolę centrów administracyjnych, mobilizacyjno-militarnych, kultowych i gospodarczych. Do grodów tego typu zalicza się dzisiaj ośrodki w Gieczu, Gnieźnie, Poznaniu i na Ostrowie Lednickim. Tutaj też w pierwszym rzędzie badacze poszukują śladów mających poświadczać chrystianizację oraz ewangelizację ,państwa gnieźnieńskiego”. Rezultaty tych poszukiwań mają zasadnicze znaczenie i dla nas, dlatego też przyjrzyjmy się (siłą rzeczy bardzo skrótowo) najważniejszym ustaleniom dotyczących wyników prac wykopaliskowych na tych obiektach.

W każdym z nich odkryto ślady murowanej zabudowy świecko-sakralnej ${ }^{4}$. Dziś na ogół uważa się, że były to w głównej mierze fundacje prestiżowe mające podkreślać pozycję władcy i jego rodu, zwracając uwagę, że monumentalna zabudowa świecka była wyraźnie dominującym elementem całego kompleksu. Skromne rozmiary kaplic oraz możliwość wejścia do nich wyłącznie od wnętrza palatiów wskazują na słuszność domysłów widzących w nich niedostępną dla ogółu ludności własność rodu panującego (ostatnio Kóčka-Krenz 2017, s. 114, 119). Pojawienie się w X-XI wieku rezydencji książęcych, a przede wszystkim towarzyszących im świątyń, najczęściej postrzegane jest jako dowód konwersji władcy i będące jej skutkiem podjęcie działań ewangelizacyjnych. Byłoby to więc równoznaczne $\mathrm{z}-$ jeśli nie z całkowitym usunięciem z grodów przejawów pogaństwa, to przynajmniej ich programowego marginalizowania. Jednakże analiza wyników badań archeologicznych prowadzonych na interesujących nas stanowiskach wydaje się pokazywać coś zupełnie innego. Wiele wskazuje bowiem na to, że Giecz i Gniezno (a niewykluczone, że również pozostałe dwa z omawianych grodów) powstały w wyraźnym powiązaniu do przedchrześcijańskich ośrodków obrzędowo-kultowych (por. Kara 2009).

Gród w Gieczu posadowiono „w cieniu” domniemanej świętej góry Górzno (Kurnatowska i Kara 2010, s. 41; Krysztofiak 2016, s. 129; Brzostowicz 2017, s. 118; inaczej Buko 2013, s. 335). Uważa się, że w latach 60. IX wieku

\footnotetext{
${ }^{4}$ Datowanie tych struktur nie będzie nas tutaj zajmować, gdyż nie ma to większego znaczenia dla podjętych rozważań. Zresztą brak w tej kwestii jednomyślności badaczy, a sam problem, przynajmniej w większości przypadków, na chwilę obecną wydaje się nie do rozstrzygnięcia.
} 
wzniesiono tutaj niewielkich rozmiarów gródek, który w 2. ćwierci X stulecia został przekształcony w silnie ufortyfikowaną dwuczłonową warownię, przejmując rolę centrum krystalizującej się na tym terenie wspólnoty terytorialnej. Dla nas jednak ważne pozostaje odkrycie na tym stanowisku (nigdy nieukończonego) zespołu rezydencjalnego na wzór innych obiektów wczesnopiastowskich. Wciąż jednak sporna pozostaje jego chronologia. Mimo że w literaturze próbuje się go łączyć już z fundacją Mieszka I (Rodzińska-Chorąży 2000, s. 369; Kóčka-Krenz 2017, s. 117), to coraz więcej zwolenników zyskuje pogląd przypisujący ją Bolesławowi Chrobremu (Krysztofiak 2016; Urbańczyk 2016, s. 146-147) lub Mieszkowi II (Danielewski 2019, s. 193; por. Śliwiński 2014, s. 150). Pozostawiając dyskusję na ten temat na inną okazję, zwróćmy uwagę na kolejne zagadnienie. Pamiętając o tym, że gród zainicjowano w relatywnie niedalekiej odległości od dominanty terenowej, odnotujemy, że pierwsze (niezasiedlone?) konstrukcje obronne w Gieczu wzniesiono w bezpośrednim sąsiedztwie „nadjeziornego miejsca obrzędowo-kultowego o starszej tradycji” (Kara 2009, s. 241; Krysztofiak 2016, s. 125). Odkryty na tym obszarze zespół zabytków archeologicznych pozwala datować jego użytkowanie na czas pomiędzy końcem IX po 2. połowę X (Kara 2009, s. 306; Krysztofiak 2016, s. 144, 146), lub nawet na przełom X/XI stulecia (na co może wskazywać informacja o XIX-wiecznym znalezisku paradnego szyszaka ruskiego i fragmentów tak datowanych naczyń ceramicznych - Kara 2009, s. 306; Wyrwa 2018, s. 95). Korelacja dotychczasowych ustaleń chronologicznych pozwala zaryzykować hipotezę, że pomiędzy X a (przynajmniej) połową kolejnego stulecia w Gieczu mogły (współ?)funkcjonować zarówno przed-, jak i chrześcijańskie obiekty związane ze sprawowaniem praktyk religijnych. Co ciekawe, nie mamy żadnych śladów mogących wskazywać, że to pierwsze zostało demonstracyjnie zniszczone. Sama zaś, ukonstytuowana upływem czasu, tradycja tego miejsca mogła zostać uwzględniona $\mathrm{w}$ decyzji przekształcenia go około połowy XI wieku w cmentarz.

Wydaje się, że zbliżona sytuacja mogła zaistnieć w Gnieźnie. Przypuszcza się bowiem, że zwornikiem lokalnego osadnictwa przegrodowego była wyraźnie manifestująca się w terenie Góra Lecha (Kurnatowska 2003, s. 37). Badania geomorfologiczne wykazały, że pierwotnie wzgórze miało dwie kulminacje. Wyższa i bardziej stroma była północna. To właśnie tutaj odkryto relikty nasypu kamiennego (,kurhanu”) interpretowanego jako miejsce kultu lub/i mogiła mitycznego przodka wspólnoty. Z kolei niższa, bardziej rozległa kulminacja, miała w tradycyjnym systemie wartości pełnić funkcję miejsca wiecowo-obrzędowego (Kara 2009, s. 177, 298-299; Sawicki 2017; inaczej Sikorski 2016, s. 26).

Analiza pozyskanych z nasypu kamiennego źródeł archeologicznych pozwoliła na określenie przybliżonego czasu jego powstania na okres między połową IX a połową X stulecia (Stawicki 2017, s. 645). Tym samym są to najstarsze ślady zagospodarowania Góry Lecha. Kres pierwotnej funkcji tego miejsca synchronizuje się $\mathrm{z}$ powstaniem grodu oraz budową kościoła (palatium?) wzniesionego 
bezpośrednio na kamiennym nasypie datowanym na przełom X i XI wieku (Sawicki 1999 , s. 24; Kara 2009, s. 300). Nie była to jednak pierwsza świątynia chrześcijańska w ośrodku gnieźnieńskim, gdyż w trakcie prac wykopaliskowych natrafiono na relikty niewielkiej rotundy wzniesionej około 2. połowy X stulecia. Dla podjętych w tym miejscu rozważań zasadnicze znaczenie ma fakt, że odkrycia te zlokalizowane były w drugim członie grodu (Kurnatowska 2010, s. 15; Matla 2017, s. 99). Przyjęcie wiarygodności suponowanych wskazań chronologicznych oznaczałoby, że przed zasypaniem dawnych struktur obrzędowych znajdujących się w północnym członie Góry Lecha, w Gnieźnie funkcjonowały dwa miejsca kultu odwołujące się do różnych tradycji religijnych. Nie jest przy tym wykluczone, że przedchrześcijańskie formy obrzędowości przetrwały tu znacznie dłużej, co sugerują wyniki badań archeologicznych wyspy położonej na pobliskim jeziorze Świętym. Wskazują one, że od schyłku VIII do XII wieku funkcjonowała tu niewielka osada (Janiak i Strzyżewski 1999, s. 37). Trudno powiedzieć, czy - jak chce Michał Kara (2009, s. 178) - zamieszkiwała ją ludność obsługującą lub/i strzegąca sanktuarium na Górze Lecha. Bardziej przekonujące są spostrzeżenia tego badacza dotyczące odbywanych na tym stanowisku czynności rytualnych (Kara 2012, s. 8-9), na co wydaje się wskazywać odkrycie śladów domniemanych ofiar w postaci szkieletów czapli. W opinii Daniela Makowieckiego (2012, s. 169): „Cechy zoologiczne ${ }^{5}$ depozytu oraz ślady ostrych narzędzi na kościach ramiennych są tu na tyle jednoznaczne w swej powtarzalności, iż nie powinno budzić wątpliwości twierdzenie, iż depozyt jest pochodzenia antropogenicznego (kulturowego), będąc efektem czynności rytualnych". Niestety, kontekst odkrycia nie pozwolił na bardziej precyzyjne określenie jego chronologii. Nie wiemy więc, czy praktyki te odbywały się przed, czy może już po wzniesieniu w Gnieźnie chrześcijańskiego miejsca kultu. Natomiast mniej stanowcze są spostrzeżenia D. Makowieckiego w stosunku do odkrytych na wyspie dwóch szkieletów psów. Z analizy dostępnych źródeł wiemy, że kości tych ssaków, zakopywane w obrębie stanowisk osadniczych, mogły pełnić ściśle określone funkcje symboliczne (Kajkowski 2018), jednakże brak bardziej szczegółowych informacji na temat gnieźnieńskiego znaleziska nie pozwala wyjść poza nawias mniej lub bardziej uzasadnionych domysłów.

Wedle opinii niektórych badaczy, kamienna konstrukcja „kurhanopodobna” odkryta w Gnieźnie mogła mieć analogie w innych ośrodkach znajdujących się pod panowaniem dynastii wczesnopiastowskiej, w tym m.in. w Poznaniu (por. Słupecki 2002, s. 32). Mimo dużego zaawansowania badań nad początkami tego ośrodka, wciąż nie umiemy odpowiedzieć, kiedy powstał tutejszy zespół rezydencjalny z dołączonym doń budynkiem służącym chrześcijańskim funkcjom sakralnym. Także w tym przypadku była to niewielka, mieszcząca zaledwie kilka osób kaplica, która miała zostać wzniesiona na prywatny użytek rodu panującego.

\footnotetext{
${ }^{5}$ Których badacz niestety nie doprecyzował.
} 
Według hipotezy M. Kara (2006), zanim na Ostrowie Tumskim stanęło monumentalne palatium, od schyłku X wieku funkcjonował tutaj duży budynek „,w typie biesiadno-kultowej hali o powierzchni co najmniej $200 \mathrm{~m}^{2}$, służący rytualnym biesiadom władcy z możnymi oraz drużyną, podczas których dokonywano aktów wymiany ceremonialnej i utrwalających poczucie elitarnej więzi". Dowodem potwierdzającym takie przeznaczenie może być nie tylko fragment Kroniki Galla (I, 13) mówiący o ucztach Bolesława Chrobrego z udziałem dwunastu najbardziej zaufanych doradców, ale także zestaw przedmiotów odkrytych w najbliższym sąsiedztwie reliktów budynku (utensylia kupieckie, monety, fragmenty drewnianych i glinianych naczyń, liczne szczątki pokonsumpcyjne) (Kara 2006, s. 115, przyp. 62). W tym kontekście na szczególną uwagę zasługuje znalezisko, jakiego dokonano przy południowo-wschodnim narożniku reliktów palatium książęcego. Okazało się bowiem, że zalegał tam niekompletny szkielet konia, który wspomniany badacz uznał za ofiarę zakładzinową. Pozyskane sekwencje stratygraficzne nie pozwoliły na jednoznaczne określenie, czy był to depozyt złożony w trakcie wznoszenia budynku halowego, czy też „nowej nawierzchni pałacu, ułożonej w 2. połowie XI w. podczas generalnej renowacji grodu" (Kara 2006, s. 115, przyp. 62). Jeśli przyjmiemy zaproponowaną interpretację, suponowane działania obrzędowe wpisywałyby się w pewien fenomen kulturowy obserwowany przede wszystkim na ziemiach objętych zwierzchnictwem administracji piastowskiej (poza Wielkopolską odnotowany przede wszystkim na ziemi lubuskiej, Kujawach i Pomorzu) i nasilającym się od około połowy XI wieku. Obserwujemy tu wyraźną korelację tego zwyczaju ze wzrostem siły oddziaływań procesów chrystianizacyjnych. W opinii niektórych archeologów proceder umieszczania w ziemi szczątków koni (jak również psów) na obszarach sepulkralnych mógł wiązać się z potrzebą podkreślenia własnej tożsamości wyznaniowej w opozycji do nowej, nie przez wszystkich akceptowanej ideologii (Kajkowski 2018, tam dyskusja i dalsza literatura). Mniej czytelne są przyczyny intensyfikacji takich depozytów na obszarach zasiedlonych, choć ich przedchrześcijańska geneza wydaje się nie budzić większych wątpliwości (Kajkowski 2016). Spostrzeżenia te korespondują z charakterystyką odkryć na Ostrowie Tumskim, które zinterpretowane zostały jako relikty funkcjonującego do około połowy XI wieku przedchrześcijańskiego miejsca kultu (Kara 2006, s. 123-124; 2009, s. 280, 355-356).

W dyskusji na temat chrystianizacji ziem polskich wyjątkowe znaczenie przypisuje się znaleziskom odkrytym na Ostrowie Lednickim. W grodzie zamkniętym potężnymi umocnieniami, w okresie transformacji społeczno-politycznych wybudowano palatium (sprzężone z kaplicą) oraz niewielki kościółek o powierzchni nieprzekraczającej $10 \mathrm{~m}^{2}$. Z tego samego stanowiska pochodzi również najliczniejszy $\mathrm{z}$ odnotowanych $\mathrm{w}$ centralnych ośrodkach wczesnopiastowskich zespół (wciąż jednak) kilku przedmiotów związanych z liturgią chrześcijańską. Zarejestrowano je w warstwie pogorzeliskowej kościółka grodowego oraz pozostałościach dwóch obiektów mieszkalnych pierwotnie usytuowanych przy północno-zachodnim 
narożniku świątyni. Powoduje to, że odkryte przedmioty łączy się albo bezpośrednio z wyposażeniem tej ostatniej (Wrzesiński i Kara 2016, s. 181-182), albo z przylegającymi do niej budynkami - w konsekwencji interpretowanymi jako miejsce zamieszkania przedstawicieli duchowieństwa (Banaszak i Tabaka 2016, s. 135). Jednak kreowaną na podstawie powyższych znalezisk wizję wybitnie chrześcijańskiego ośrodka zaburzają, na ogół pomijane w dyskusji, wyniki badań Jana Leśne$\mathrm{go}^{6}$. Już w latach 70. minionego stulecia badacz ten odsłonił relikty budynku zrębowego, pod którego fundamentami zachowały się depozyty w postaci zdekompletowanych szkieletów dwóch koni. Pod glinianym klepiskiem znajdowały się jeszcze kości krowy, których układ może sugerować, że pierwotnie także i to zwierzę złożono z zachowaniem porządku anatomicznego. W odległości około $1 \mathrm{~m}$ od zewnętrznej linii zachodniej ściany zarejestrowano jeszcze czaszkę należącą do trzeciego konia (Leśny 1974). Wyróżniające się rozmiary konstrukcji o długości dochodzącej niemal $4 \mathrm{~m}$, położenie nad brzegiem jeziora ${ }^{7}$, natężenie umieszczonych pod nim (i pozbawionych śladów mechanicznej obróbki) kości oraz domniemanie zdobienia bryły budynku czaszką (względnie kilkoma) końską, skłoniły Leśnego do uznania odkrytych reliktów za pozostałości pogańskiego miejsca kultu. Na podstawie dotychczasowej wiedzy nie jesteśmy w stanie zweryfikować tej hipotezy, jakkolwiek wyjątkowość odkryć w skali osadnictwa grodu lednickiego wydaje się nie budzić większych wątpliwości. Dla podjętych w tym miejscu rozważań ważne pozostają również ustalenia chronologiczne odnoszące opisywane struktury do XI stulecia. Oznacza to, że - bez względu na to, któremu z dwóch pierwszych Piastów przypiszemy rolę fundatora tutejszych świątyń chrześcijańskich - funkcjonowały one synchronicznie z budynkiem odkrytym na podgrodziu. Nie bez znaczenia pozostają również ustalenia, wedle których wzniesiony z inicjatywy piastowskiej gród posadowiono na zniwelowanych reliktach stojącego tu wcześniej obiektu kultowego, jak również to, że właśnie w tym miejscu ,wpuszczone zostały [...] kamienne fundamenty preromańskiego pałacu z kaplicą/baptysterium” (Kara 2009, s. 353). Jeśli przyjąć prawdopodobieństwo takiego przebiegu wydarzeń, sytuacja zanotowana na Ostrowie Lednickim wpisywałaby się w proces świadomej adaptacji dawnych struktur sakralnych i włączania tradycji tych miejsc do nowych potrzeb, przy jednoczesnej tolerancji obiektów przedchrześcijańskich zlokalizowanych poza zwartym pierścieniem siedziby władcy.

To ostatnie spostrzeżenie wzmocnić można dalszymi przykładami. Okazuje się bowiem, że centralny gród piastowski na wyspie Jeziora Lednickiego wybudowano na warstwie rozwleczonej próchnicy nasyconej śladami po paleniu ognia.

\footnotetext{
${ }^{6}$ Ostatnio wrócili do nich Danuta Banaszak i Arkadiusz Tabaka (2020), jednak ustalenia tych autorów nic nie wnoszą do dyskusji, zupełnie ignorując nowsze ustalenia badaczy reliktów tradycyjnej religijności Słowian.

${ }^{7}$ Nabierające większego znaczenia, jeśli weźmiemy pod uwagę suponowaną genezę licznych militariów zalegających na dnie zbiornika, które badacze coraz częściej łączą z przedchrześcijańską obrzędowością wotywną (szerzej na ten temat Kajkowski 2019, s. 230-233).
} 
Możliwe więc, że możemy mieć tutaj do czynienia z notowaną na obszarze całej Słowiańszczyzny praktyką rytualnej puryzacji wynikającą z performatywnej roli tego żywiołu w wierzeniach tradycyjnych (podobnie Wrzesiński i Kara 2016, s. 83, 95). W związku z tym warto zwrócić uwagę na zespół spalonych monet i ozdób, które odkryto $\mathrm{w}$ bezpośrednim kontekście południowej części wału obronnego (Tabaka 2013, s. 23-24).

Relikty działań o zbliżonych treściach nieznajdujących uzasadnienia w praktykach chrześcijańskich odnajdujemy także w obrębie pozostałych analizowanych grodów wczesnopiastowskich. Poza wspomnianym już szkieletem konia z poznańskiego Ostrowa Tumskiego z XI stuleciem łączyć można czaszkę krowy odkrytą pod wałem grodu gnieźnieńskiego (Hilczer-Kurnatowska 1982, s. 53-54). Niewiele starszy jest datowany na schyłek $\mathrm{X}$ wieku szkielet niemowlęcia interpretowany jako ofiara zakładzinowa, który odkryto na osadzie w Śródce - najprawdopodobniej będącej zapleczem grodu poznańskiego (Pawlak i Pawlak 2019, s. 165). Jako czynności apotropaiczne interpretuje się również jeden z elementów konstrukcyjnych umocnień obronnych. Na jednym z haków spajających konstrukcję wału wyrzeźbiono bowiem zwierzęcy łeb na ogół interpretowany jako wyobrażenie dzika, ssaka mogącego odgrywać znaczącą rolę w życiu religijnym (w tym magii wojennej) wspólnot zachodniosłowiańskich (Kajkowski 2017, s. 245-256). Zbliżone symbolicznie treści mogło skrywać także poroże jelenia odnotowane wewnątrz wału grodu gieckiego (Wyrwa 2016, s. 35).

W kontekście poruszanych zagadnień interesująco przedstawia się problem obecności przedmiotów mogących poświadczać nie tylko sprawowanie liturgii, ale również świadomą konwersję ludności żyjącej pod rządami pierwszej monarchii piastowskiej. Okazuje się jednak, że poza unikatowym zespołem zabytków z Ostrowa Lednickiego, zaledwie dwa kolejne (w postaci fragmentów relikwiarza skrzynkowego i dzwonu) odkryto w trakcie badań niedokończonego palatium w Gieczu (Kóčka-Krenz 2017, s. 117). Tak niewielka liczba znalezisk łączonych z chrześcijaństwem jest nieproporcjonalnie niska w porównaniu z sytuacją zaobserwowaną na datowanych na X i początek XI wieku stanowiskach w Czechach i na Rusi, skąd pochodzi spora liczba takich odkryć. Jak słusznie zauważył Marcin Wołoszyn (2011, s. 18-19), odróżnia to ziemie polskie nie tylko od najbliższych sąsiadów, ale także Austrii, Węgier czy Szwecji.

Z kolei z kultem pogańskim łączyć można szereg dalszych zabytków pozyskanych w trakcie badań omawianych grodów: wykonane z metali kolorowych miniaturowe wyobrażenia koni ${ }^{8}$ (Łukaszyk 2012, s. 126), zawieszki mogące spełniać rolę amuletów lub/i identyfikatorów (tzw. markerów) kulturowych (fragmenty okuć pochewek noży ze zdobieniami zoomorficznymi, kaptorgi, lunule, szkliwiona gwiazda, kości zwierząt) (Kaczmarek 1998, s. 558; Indycka 2000; 2008; Gardeła, Kajkowski i Ratajczyk 2019). Przejawem tradycyjnych form obrzędowości mogą

\footnotetext{
${ }^{8}$ Znamienne, że z Giecza znamy największy w Polsce zbiór takich figurek.
} 
być także grzechotki/pisanki lub jaja (Miciak 2017) i - choć tutaj trudno o zdecydowany osąd - drewniany krążek zdobiony ornamentem mogącym symbolizować ciała niebieskie (?). W związku z podjętymi rozważaniami na szczególną uwagę zasługuje także sposób ornamentacji niektórych przedmiotów łączonych bezpośrednio z elitami piastowskimi. Mam tutaj na myśli zdobienia zoomorficzne o kształcie przypominającym węża lub smoka. Motyw ten pojawia się przede wszystkim na zabytkach (militaria, oporządzenie jeździeckie, okładziny sierpów), których charakter wskazuje, że mogły należeć do stacjonujących w sedes regni principales wojów, najpewniej członków książęcej drużyny, obecnych nie tylko w przywołanych wyżej grodach, ale również innych ośrodkach o dużym znaczeniu strategicznym w polityce Piastów. Spotykamy je także w wyposażeniu kilku grobów usytuowanych w pobliżu tych ośrodków. W literaturze wysunięto hipotezę, iż taki sposób zdobienia może być odczytywany jako ideogram nawiązujący do przedchrześcijańskiej wizji świata (Gardeła, Kajkowski i Ratajczyk 2019, tam dyskusja i dalsza literatura). W takim rozumieniu funkcją tych artefaktów mogła być nie tyle (czy może nie tylko) chęć/potrzeba manifestacji statusu, ile odwołania się do protekcji określonych sił nadprzyrodzonych, mogących jednocześnie wskazywać na przekonanie o sakralnym pochodzeniu rodu piastowskiego.

Z przeprowadzonej analizy wyników badań archeologicznych wynika dość ważny dla podjętych tu zagadnień wniosek. Okazuje się bowiem, że bilans porównania natężenia występowania przedmiotów mogących nawiązywać do wierzeń tradycyjnych i akcesoriów liturgicznych oraz dewocjonaliów chrześcijańskich wypada tu wyraźnie na niekorzyść tych ostatnich.

Na koniec tej części rozważań warto zwrócić jeszcze uwagę na obserwacje dotyczące źródeł nekropolicznych. Siłą rzeczy naszą uwagę skierujemy tu przede wszystkim na cmentarze lokowane w najbliższym sąsiedztwie interesujących nas ośrodków grodowych, gdyż to właśnie tutaj powinna być chowana zamieszkująca je ludność.

W opinii części badaczy, jedną z najbardziej dystynktywnych cech mających dowodzić świadomej recepcji chrześcijaństwa jest wprowadzenie inhumacji. Niestety, wciąż nie jesteśmy w stanie określić, kiedy dokładnie pojawiła się ona w dominium rodu Piastów. W świetle dotychczasowej wiedzy nie możemy datować jej wcześniej niż na schyłek X lub pewniej na początek XI wieku. Jednak według ustaleń archeologów, najstarsze groby szkieletowe odnotowane w centrum państwa piastowskiego niekoniecznie skrywały szczątki członków lokalnych społeczności (por. Matla 2017, s. 67). Czy - mając na uwadze powyższe spostrzeżenia - rzeczywiście taki sposób składania zwłok w jamach grobowych należy wiązać wyłącznie z procesem chrystianizacji (por. Rębkowski 2007, s. 515; Dulinicz 2009, s. 383)? Przy próbie udzielenia odpowiedzi na to pytanie warto rozważyć trzy wątki problemowe. Pierwszym z nich jest - skądinąd często podkreślany przez badaczy zwyczajów funeralnych doby transformacji religijnej - brak regulacji kościelnych nakazujących chowanie zmarłych niespalonych. Drugim musi być pewna 
niekonsekwencja, którą obserwujemy w interpretacjach źródeł nekropolicznych. $\mathrm{Z}$ jednej bowiem strony $\mathrm{w}$ literaturze przedmiotu podkreśla się przywiązanie społeczności słowiańskich do tradycyjnych form obrzędowości (a w konsekwencji wyjątkowy opór w akceptacji zwyczajów chrześcijańskich), z drugiej zaś oczekuje świadectw szybkiej i masowej konwersji. Ta ostatnia powinna zaś mieć wyraźne poświadczenie w świadectwach materialnych - także eschatologicznych. I w końcu trzeci problem, który można ująć w kilku pytaniach: dlaczego zwyczaje pogrzebowe miałyby zostać schrystianizowane tylko w zakresie sposobu chowania zwłok? Dlaczego proces zmian eschatologicznych nie dotknął wszystkich członków lokalnych społeczności? I w końcu, dlaczego za dawne - pogańskie uznaje się pewne zwyczaje, których nie notuje się we wcześniejszej tradycji ciałopalnej (nietypowy układ ciała, odmienna orientacja zwłok, przygniatanie określonych partii ciała kamieniami, częściowe nadpalanie zwłok, wtórne otwieranie grobów i wydobywanie z nich określonych części szkieletu, składanie konkretnych przedmiotów w ściśle określonym ułożeniu w stosunku do szczątków ludzkich)? Przecież wszystkie te praktyki związane ze złożeniem w grobie doczesnych szczątków zmarłych mogły zaistnieć tylko z pojawieniem się inhumacji.

Trudno dziś udzielić wyczerpujących odpowiedzi na postawione wyżej pytania, zresztą nie to jest celem niniejszych rozważań. Dla nas ważne pozostaje spostrzeżenie, że na wielu cmentarzach użytkowanych przez społeczności wchodzące w skład państwa wczesnopiastowskiego notujemy liczne elementy będące lub wynikające z tradycji przedchrześcijańskich ${ }^{10}$.

Podsumowując tę część rozważań, wypada zauważyć, że jeśli rzeczywiście obecność monumentalnej architektury rezydencjalnej poświadcza, że począwszy od połowy XI (lub jak chcą niektórzy badacze od schyłku X) stulecia w głównych ośrodkach państwa piastowskiego rozgrywały się wydarzenia w konsekwencji ważne dla rozwoju Kościoła polskiego, to jednocześnie nie obserwujemy ani w tym czasie, ani w późniejszym stuleciu programowego ograniczania aktywności środowisk przedchrześcijańskich. Zarówno charakter, jak i liczba odkrywanych reliktów obrzędowości i manifestacji dawnych tradycji może sugerować, że środowiska te

${ }^{9}$ Co wydaje się poświadczać współwystępowanie grobów ciałopalnych i szkieletowych w obrębie jednego cmentarzyska w tym samym lub zbliżonym czasie (obecne na cmentarzach do końca wczesnego średniowiecza). Problemu nie wyjaśnia ani uznanie tych pierwszych za groby osób o innym pochodzeniu etnicznym, ani za świadectwo różnic społecznych definiujących wspólnotę użytkującą nekropolę. W wyniku podjętych przez nas problemów nie przekonuje też próba uznania ich za miejsca spoczynku pogan, podczas gdy w pozostałych mieliby zostać złożeni wyznawcy Chrystusa.

10 Poza przywołanymi już przykładami, warto tutaj wspomnieć jeszcze o trwających lub pojawiających się w XI stuleciu i nieznajdujących potwierdzenia w zwyczajach chrześcijańskich formach grobów (komorowych i w obstawach kamiennych), zachowaniach obrzędowych (palenie ognia w jamach i obok grobów), depozycji szczątków zwierzęcych oraz śladach manipulacji nimi (rozczłonkowanie, odjęcie kopyt), składania w jamie grobowej kości zwierzęcych, ziaren zbóż czy przedmiotów takich, jak jaja, wiadra, monety-obol zmarłych, przedmiotów o metryce pradziejowej, tzw. archaików, amuletów (kaptorgi, lunule, szkliwiona gwiazda, zawieszki z kości zwierzą), grzechotki, klucz, kłódka. 
nie zostały zepchnięte do podziemia, ani też nie obejmowały zasięgiem wyłącznie ośrodków położonych na prowincji ziem poddanych kontroli Piastów. Spostrzeżenia te - jak widzieliśmy - wydają się znajdować potwierdzenie w obserwacjach wynikających z analizy źródeł nekropolicznych. Mimo wyraźnej dominacji poglądów wiążących recepcję inhumacji z wpływami chrześcijaństwa, coraz częściej wskazuje się, że zwyczaj chowania zmarłych niespalonych mógł wynikać z przeobrażeń zachodzących w eschatologii tradycyjnej (tak już Zoll-Adamikowa 1998, s. 237) lub adaptacji wzorców zewnętrznych. Jako uzasadnienie tego punktu widzenia można wskazać obecność pochówków tego rodzaju notowanych tu przed chrystianizacją. W tym kontekście ważnym argumentem może być fakt, że formalnie Kościół nie wskazywał na konieczność stosowania ściśle określonych wymogów w tym zakresie (Rębkowski 2006, s. 516). Z drugiej zaś strony wskazuje się również na różnice występujące na poziomie regionalnym, czy nawet zmiany w samej obrzędowości chrześcijańskiej (Rębkowski 2007).

Spróbujmy więc podsumować dotychczasowe uwagi dotyczące postępów chrystianizacji i odpowiedzieć na pytanie:

\section{CZY W MONARCHII WCZESNOPIASTOWSKIEJ W LATACH 30. XI WIEKU DOSZŁO DO KONFLIKTU WYZNANIOWEGO?}

Uważna lektura dostępnych nam źródeł pisanych podparta analizą wyników badań archeologicznych wydaje się stawiać problem chrystianizacji Polski i recepcji nowej ideologii nieco inaczej, niż nakreśla ją większość dotychczasowych opracowań naukowych. Trudno tu bowiem mówić nie tylko o „niebudzącej wątpliwości chrystianizacji państwa polańskiego w X wieku" (Małachowicz 2008, s. 161), ale także w kolejnych stuleciach. Jak wynika z treści dekretu papieża Innocentego III, jeszcze na początku XIII wieku w kościołach archidiecezji gnieźnieńskiej odbywały się obrzędy odprawiane ku czci zmarłych, w których brała udział nie tylko miejscowa ludność, ale także lokalni duszpasterze wraz ze swoimi dziećmi (Burchardt 1986, s. 35). Powoduje to, że część historyków stoi na stanowisku, że „nawrócenie Polski trzeba liczyć [...] od [panowania] Kazimierza Odnowiciela, a nie 'oficjalnie' od Mieszka I-go, jak to zwykle się robi” (Potkański 1924, s. 74). Powyższe stwierdzenia wydają się znajdować oparcie w datowaniu wykrystalizowania trwałej organizacji kościelnej gwarantującej skuteczny proces ewangelizacji. W Polsce ustanowiono ją dopiero w XIII wieku (Urbańczyk 2016, s. 160), natomiast w połowie XI liczba chrześcijańskich obiektów sakralnych w obrębie państwa gnieźnieńskiego najpewniej nie przekraczała dwudziestu (Kurnatowska 2000, s. 120; Sikorski 2017, s. 220). Wszystkie były jednak własnością władców, a kryjące się za tymi fundacjami intencje wciąż pozostają dla nas niejasne. Materiał źródłowy nie daje odpowiedzi, czy postawiono je z myślą o obsłudze elit skupionych wokół głównych grodów, podkreślenia prestiżu i międzynarodowego 
autorytetu Piastów i/lub realizacji ideału „władcy-fundatora”, wyrażania ich pobożności (Dowiat 1961a, s. 110; 1961b, s. 16; Michałowski 2008, s. 16; Wiszewski 2008, s. 464), czy też mogły pełnić funkcje propagandowe mające dowodzić tej pobożności w oczach „obserwatorów z Zachodu”? Bez względu na preferowaną odpowiedź nie może ulegać wątpliwości, że uchwytne źródłowo działania pierwszych Piastów ostatecznie doprowadziły do trwałego włączenia Polski w krąg wpływów kultury łacińskiej. Te same źródła wskazują jednocześnie na pewną bierność i brak zaangażowania $\mathrm{w}$ prowadzeniu akcji misyjnej, i to nie tylko na obszarach peryferyjnych, ale przede wszystkim w ścisłym centrum „państwa gnieźnieńskiego" "'. Co więcej, wiele wskazuje też na to, że chrześcijanie stanowili tutaj mniejszość przy wyraźnej dominacji wyznawców tradycyjnego systemu wierzeń ${ }^{12}$. Najbardziej wymownym przykładem tych ostatnich - wbrew stanowczemu sprzeciwowi niektórych badaczy (np. Tyszkiewicz 2016, s. 210) - mogą być notowane w trakcie badań wykopaliskowych ślady przedchrześcijańskiej obrzędowości i związanych $\mathrm{z}$ nią przedmiotów.

Rację trzeba też przyznać tym uczonym, którzy wskazują, że proces konwersji dokonał się na poziomie elit społecznych. $Z$ tym jednak zastrzeżeniem, że nie wszystkich, a niewykluczone, że były to jedynie akty o charakterze jednostkowym (skupiającym być może osoby z najbliższego otoczenia administracji piastowskiej) $)^{13}$. Nie można jednak wykluczać i tej możliwości, że chrystianizacji poddały się większe grupy ludzkie, które nie porzuciły dawnego systemu wartości. Może więc rację miał Paweł Jasienica (1961, s. 55), pisząc, że „ci Polacy, których w roku 966 zanurzono w wodzie święconej i uznano za synów Kościoła rzymskiego, w gruncie rzeczy powrócili do domów tym samym, czym byli idąc na uroczystość chrztu - ludźmi ukształtowanymi przez starą, rodzimą kulturę, duszami otwartymi na nowe wpływy, lecz jednocześnie żyjącymi dziedzictwem". W oczach pogan nie była to sytuacja wyjątkowa (jeszcze do tego wrócimy). Natomiast Kościół, ze względów doktrynalnych, nie mógł zaakceptować sytuacji, że dla świeżo pozyskanych konwertytów chrzest nie łączył się z - jak to ujął Stephen Rowell (2017, s. 143) - pożądaną, ciągłą metanoia, ale mógł być jedynie chwilową zmianą wynikającą z potrzeby chwili.

W taki sposób mogli być również postrzegani nie tylko ich poddani, ale i sami Piastowie. To, jak odbierały tych ostatnich elity zachodnioeuropejskie, obrazują niektóre zapisy źródłowe, charakteryzując ich jako barbarzyńców, „półchrześcijan”,

11 Warto przy tym pamiętać o zaangażowaniu Bolesława Chrobrego w działania misyjne prowadzone na zewnątrz (ziemie bałtyjskie, Szwecja), co wydaje się dość znamienne.

12 Chyba że ci pierwsi z jakichś względów nie mogli lub nie czuli potrzeby zewnętrznej manifestacji swojego wyznania.

13 W tym kontekście niezwykle interesująco jawi się spostrzeżenie Jerzego Strzelczyka, który zwrócił uwagę na milczenie źródeł w kwestii konwersji przedstawicieli (innych poza Mieszkiem i Bolesławem Chrobrym) dynastii panującej, co - w opinii historyka - mogło wynikać z „opowiedzenia się tego czy innego Piastowicza przy tradycyjnej religii” (Strzelczyk 2016, s. 22). 
czy wręcz „obrońców starodawnej wiary słowiańskiej”. Czy było to wynikiem niechęci cesarstwa do wyrastającego na wschodzie silnego organizmu politycznego, czy też oddawało ówczesną rzeczywistość, nie sposób odpowiedzieć. Zresztą, jedno nie wyklucza drugiego.

Jeśli przyjmiemy zasadność dokonanych dotąd ustaleń, to wynikające $\mathrm{z}$ nich wnioski skłaniają do przewartościowania dominujących w (szczególnie starszej) literaturze poglądów dotyczących wprowadzenia chrześcijaństwa i rozwoju związanych z nim wczesnopiastowskich struktur kościelnych. Wskazywany tu szybki i skuteczny przebieg opisywanych procesów trwał znacznie dłużej, a ostateczny sukces wcale nie musiał wynikać ze słabości dotychczasowej organizacji kultu i mniej atrakcyjnych dla swoich wyznawców (!) wierzeń (Dowiat 1962, s. 84; Hensel 1984, s. 35). Musiały one spełniać oczekiwania swoich wyznawców, skoro jednak ich nie porzucono (Strzelczyk 2001, s. 51; 2017, s. 69-70; inaczej Sikorski 2017, s. 67).

Jak zatem tłumaczyć stwierdzenie, że ,wprowadzenie chrześcijaństwa nie musiało wywołać żadnych napięć społecznych, tym bardziej, że chrystianizacja nie odbywała się pod przymusem?” (Sikorski 2016, s. 27). Wydaje się - i tu wracamy do przerwanego wyżej wątku - że rozwiązania należy szukać w charakterze pogańskiego systemu ideologicznego. Pozwalał on bowiem włączać do istniejącego panteonu kolejne - szczególnie bardziej efektywne - bóstwa (względnie inne istoty nadprzyrodzone czy herosów kulturowych) bez potrzeby podważania istnienia i kompetencji dotychczasowych. Najprawdopodobniej właśnie z taką sytuacją możemy mieć do czynienia w XII-wiecznym Szczecinie, w którym - jeśli wierzyć hagiografom Ottona z Bambergu - postawiono „ołtarze” zarówno dla Boga chrześcijan, jak i własnych (VP III, 5) ${ }^{14}$. Z podobną sytuacją mamy do czynienia w przypadku katedry gnieźnieńskiej, w której w połowie XI wieku miejscowa ludność chciała odprawiać najprawdopodobniej usankcjonowane wcześniejszą tradycją magiczne obrzędy (Burchardt 1986). Nie była to zresztą sytuacja w ówczesnej Europie odosobniona. Boga chrześcijan do lokalnego panteonu włączyli także inni władcy, by wspomnieć choćby anglosaskiego Raedwalda czy węgierskiego Gezę (Słupecki 1994, s. 76). I nie chodziło tu bynajmniej o ,ścieranie się i godzenie starego i nowego porządku" (Gieysztor 1960, s. 936).

Ze względu na milczenie źródeł nie sposób udzielić odpowiedzi na pytanie, czy podobne wydarzenia mogły zaistnieć już od czasów panowania Mieszka I. Gdybyśmy jednak przyjęli, że pogaństwo „Polan”, przynajmniej w głównych założeniach, nie odbiegało od tradycji religijnej innych społeczności słowiańskich tego okresu, jest to trop obiecujący. Wpisuje się on również w ogólną charakterystykę mentalności średniowiecznych społeczności, pośród których percepcja ewoluującej rzeczywistości światopoglądowej w znacznym stopniu opierała się na odnoszeniu

${ }^{14}$ Nie inaczej też należy chyba potraktować propozycję możnych słowiańskich wysuniętą do księcia saskiego Henryka Lwa, któremu poganie mieli zaproponować pozycję porównywalną z boską (Helmold I, 84). 
nowego do starego (Guriewicz 1987, s. 29). W takiej sytuacji idea boskości mogła być ukierunkowana kulturowo, a jej rozumienie wynikać z ewolucji pojęć dostosowywanych do aktualnego poziomu rozwoju systemu religijnego (Campbell 2007, s. 121). Tym samym, jeśli rację ma Marc Augé (2010, s. 11), twierdząc, iż „pogaństwo zakłada, że wszystkie zdarzenia są znakiem i że wszystkie znaki mają sens” oraz że ,zawsze skłonne do wydłużenia listy bogów, dopuszcza dodawanie i zmianę, ale nie syntezę", to za taki znak mogły uchodzić sukcesy militarne i polityczne władców odwołujących się do protekcji chrześcijańskich sił nadprzyrodzonych. Klęski elementarne, niepowodzenia na polach bitew, brak zaufania - to wszystko mogło doprowadzić do chwilowego lub trwałego odwrócenia się wyznawców od dotychczas czczonego boga (bądź bogów) lub/i postawienia na czele panteonu boga skuteczniejszego. Nie musiało to jednak wpływać na dotychczasowy porządek normatywny i powoduje, że bez względu na skalę tego zjawiska „chrześcijaństwo tego okresu postrzegać należy bardziej w kategorii modelu kulturowego niż rzeczywistej konwersji” (Janowski 2015, s. 93).

Zagadnieniom chrystianizacji nie możemy poświęcić już więcej miejsca. Jednakże już to, co zdołaliśmy ustalić do tej pory, wydaje się wystarczającą podstawą do dalszych wniosków związanych już bezpośrednio z tematem podjętych tu rozważań.

\section{CZY ZA RZĄDÓW MIESZKA II DOSZŁO DO REAKCJI POGAŃSKIEJ?}

Parafrazując słowa amerykańskiego antropologa i socjologa Marvina Harrisa, możemy zadać pytanie, czy za czasów Mieszka II podległa mu ludność znajdowała się w na tyle niekorzystnym położeniu, by chwytać się desperackich sposobów walki z aparatem władzy? Czy widmo alternatywy było „tak odrażające, iż warto [było] podjąć nawet wielkie ryzyko" (Harris 1985, s. 169-170)? I w końcu - tu już z naszych dociekań - jaka była w tym wszystkim rola Kościoła i chrześcijan?

W dotychczasowej dyskusji nad zagadnieniem przyczyn wybuchu ,reakcji pogańskiej” doszukuje się nie tyle (czy może nie tylko) w trudnościach z przyswajaniem chrześcijaństwa, ile w obciążeniach fiskalnych na rzecz Kościoła i w obcości skupionych wokół władcy przedstawicieli duchowieństwa (por. Śliwiński 2014, s. 235; Sikorski 2016, s. 33 i nn.; 2017, s. 218). Pierwszy z powyższych argumentów spotkał się ostatnio ze słuszną krytyką Dariusza Sikorskiego, który wyraźnie podkreśla, że w interesującym nas czasie ,jedynym oparciem finansowym i organizacyjnym dla Kościoła była monarchia" (Sikorski 2016, s. 33). Skoro więc to władca finansował budowę świątyń i ponosił koszta utrzymania zarówno biskupów, jak i kleru diecezjalnego, to obciążenia te nie mogły dotykać ludności poddanej jego opiece.

Więcej racji wydają się mieć zwolennicy drugiego poglądu podążający za dominującą w literaturze opinią, że ,znaczny odsetek wśród kleru, a zwłaszcza wśród członków hierarchii kościelnej w krajach 'Młodszej Europy' od X do co najmniej schyłku XII wieku musieli stanowić cudzoziemcy - głównie przybysze z obszaru 
Rzeszy" (Pauk 2017, s. 263). Wskazuje się przy tym, że taka polityka faworyzowania obcych mogła dawać władcy gwarancję lojalności. Na ogół przybysze nie mieli bowiem oparcia w lokalnych środowiskach możnowładczych mogących kierować się własnymi aspiracjami i ambicjami (Pauk 2017, s. 267). Jeśli rację ma anonimowy kronikarz z Brauweiler, to w czasach panowania Mieszka II był to poważny problem mogący skutecznie ograniczać status miejscowych elit. Z kart kroniki dowiadujemy się bowiem, że „królowa Rycheza, dokonawszy rozwodu z królem mężem swoim tak w powodu nienawiści i podjudzania niejakiej nałożnicy [...] ze wzgardy dla nieznośnego, jednocześnie i barbarzyńskiego godnego wzgardy obrządku Słowian, przybyła do Saksonii do cesarza" (za Strzelczyk 2012, s. 21). Podkreślana tu niechęć do obrządku Słowian, jeśli rzeczywiście była faktem (por. Delimata-Proch 2019, s. 172 i nn., gdzie szczegółowe omówienie problemu), mogła powodować potrzebę otaczania się przybyszami z zewnątrz. Jeśli do tego zgodzimy się z poglądem, że większość finansowanych przez Mieszka fundacji kościelnych doszła do skutku pod wpływem królowej (co znajduje zresztą potwierdzenie w przejmowaniu z Rzeszy patrociniów - Labuda 2008, s. 44-50; Wiszewski 2008, s. 78; Matla 2017, s. 175), to pogląd ten nabiera mocniejszych podstaw.

Niewykluczone, że jednym z poważniejszych problemów mogących przyczynić się do upadku władzy Piasta były zmiany w dotychczasowej gospodarce finansowej państwa (podobnie Urbańczyk 2015, s. 126). A konkretnie rezygnacji z dochodowego handlu niewolnikami, z którego zresztą Mieszko początkowo również czerpał zyski. Niestety, źródła nie precyzują, co legło u podstaw takiej decyzji króla. Możliwe, że stała za nią postawa duchowieństwa. Jeśli rację ma Długosz, prawiąc o dużych ciężarach podatkowych, jakimi Mieszko obciążał swoich poddanych, a jednocześnie uświadomimy sobie, jakie sumy musiało pochłaniać utrzymanie drużyny, sprawnej administracji państwowej, licznych fundacji kościelnych czy budowy palatiów, łatwiej będzie zrozumieć, jakie skutki mogła wprowadzić rezygnacja ze sprzedaży tak dochodowego towaru, jakim byli ludzie. Co więcej - a może nawet przede wszystkim - decyzja ta uderzała także w interesy elit skupionych wokół głównych ośrodków grodowych i musiała powodować bezpośredni konflikt skutkujący rozejściem się interesów tej grupy społecznej oraz władcy.

Ale czy słuszność mają ci spośród uczonych, którzy przedstawicielom elit (czy samemu Bezprymowi) każą poderwać tłumy pogan, dającym przy okazji upust nienawiści do chrześcijaństwa? Chyba nie, skoro nie wyładowano jej na służącym mu świątyniom. Kościoły (a zapewne i grody) w Gnieźnie i Poznaniu złupił i do ruiny doprowadził dopiero najazd czeskiego Brzetysława ${ }^{15}$, a - jak słusznie

${ }^{15}$ Część badaczy stoi tu jednak na stanowisku, że obie świątynie mogły przetrwać ze względu na to, że „wystąpienia antychrześcijańskie [...] objęły przede wszystkim prowincję. Kościoły przetrwały właśnie tam, gdzie struktury władzy były najsilniejsze, tj. w stołecznych ośrodkach państwa" (Górczak 2000, s. 115 i nn., Śliwiński 2014, s. 207). Dotychczasowe wyniki badań archeologicznych, pomijając dyskusyjne datowanie niektórych świątyń na czasy pierwszej monarchii piastowskiej, nie dają podstaw do takiej interpretacji. 
skonstatował Karol Modzelewski (1987, s. 257) - „,przytoczony przez Kosmasa rejestr skarbów, które Brzetysław wywiózł z Gniezna i Poznania, jest widomym dowodem, że stolice pierwszych Piastów nigdy nie dostały się w ręce zbuntowanej ludności [...]”.

Wydaje się, że równie ostrożnie należy traktować podnoszone w źródłach prześladowania i zabójstwa „biskupów i kapłanów”. Dużo przemawia za tym, że rację należy przyznać tym badaczom, którzy z jednej strony podkreślają emocjonalne podejście opisujących te wydarzenia autorów (będących przecież „ludźmi Kościoła"; Borawska 1964, s. 180), z drugiej zaś wskazują, iż śmierć któregoś w ówczesnych biskupów w obronie wiary musiałaby spowodować rychłą kanonizację, a o takich nic nie wiemy (Śliwiński 2014, s. 206). Jeśli jakieś prześladowania duchowieństwa rzeczywiście miały miejsce, to w kontekście tego, co ustaliliśmy wyżej, należałoby je łączyć z pozycją, jaką jego przedstawiciele zajmowali w strukturach administracyjnych państwa gnieźnieńskiego, ,a nie jako wyraz odrodzenia pogaństwa krwawo rozprawiającego się z chrześcijańską konkurencją" (Sikorski 2016, s. 36). Wiele wskazuje więc na to, że obalenie struktur kościelnych nie leżało w intencji środowisk odpowiedzialnych za wydarzenia $\mathrm{z}$ lat 30. XI wieku. Struktury te były wówczas zależne wyłącznie od władzy Piastów, którzy ponosili także całkowity koszt ich utrzymania. Nie ma informacji źródłowych, które wskazywałyby na fundacje finansowane przez przedstawicieli wyższych warstw społecznych, a interpretacja funkcji i symboliki przypisywanych tej grupie przedmiotów odnajdowanych w newralgicznych ośrodkach państwa gnieźnieńskiego, wskazuje jeśli nie brak, to połowiczną jej chrystianizację. Pozostała część ludności najprawdopodobniej tkwiła przy tradycyjnym systemie wartości. Nie dziwi więc, że pozbawiony zaplecza społecznego Kościół upadł wraz z klęską aparatu władzy. Jeśli przypuszczenia te są słuszne, to zaburzenia lat 30. XI wieku nie mogły mieć charakteru rewolucji pogańskiej nacechowanej ostracyzmem religijnym, gdyż w państwie pierwszych Piastów nie doszło do żadnego konfliktu wyznaniowego.

\section{BIBLIOGRAFIA}

\section{Źródła}

Długosz 1961, Jan Długosz, Roczniki czyli kroniki sławnego Królestwa Polskiego, Warszawa.

Gall 1989, Anonim tzw. Gall, Kronika polska, wyd. R. Grodecki, Wrocław-Warszawa-Kraków-GdańskŁódź.

Helmold 1974, Helmolda Kronika Stowian, wyd. J. Strzelczyk, Warszawa.

Thietmar 2002, Kronika Thietmara, tłum. M.Z. Jedlicki, Kraków.

VP 1872, Monachi Priefliengensis vita Ottonis episcopi babenbergensis, w: A. Bielowski wyd., Monumenta Poloniae Historica. Pomniki dziejowe Polski, t. 2, Lwów. 


\section{Opracowania}

Augé M. 2010, Duch pogaństwa, Warszawa, Oficyna Naukowa Volumen.

Banaszak D., Tabaka A. 2016, Drewniane budownictwo mieszkalne, w: Z. Kurnatowska, A.M. Wyrwa (red.), Ostrów Lednicki. Rezydencjalno-stołeczny ośrodek pierwszych Piastów, Warszawa, IAiE PAN, s. $130-141$.

- 2020, Ślady wierzeń pogańskich na przykładzie znalezisk z Ostrowa Lednickiego, „Slavia Antiqua” 61, s. 117-134.

Banaszkiewicz J. 2014, Trzy po trzy o dziewiatym wieku, Kraków, Avalon.

Borawska D. 1964, Kryzys monarchii wczesnopiastowskiej w latach trzydziestych XI wieku, Warszawa, PWN.

Brojer W. 2014, Polska - Ruś w XI-XII wieku. Granica misyjności, w: Z. Dalewski (red.), Granica wschodnia cywilizacji zachodniej w średniowieczu, Warszawa, IH PAN, s. 297-373.

Brzostowicz M. 2017, A może Poznań? W poszukiwaniu gniazda rodowego Piastów, w: A. Różański (red.), Gemma Gemmarum. Studia dedykowane Profesor Hannie Kóčce-Krenz, Część pierwsza, Poznań, Wydawnictwo PTPN, s. 111-129.

Buko A. 2013, Najstarsze ośrodki Piastów w świetle archeologii, w: J. Banaszkiewicz, M. Kara, H. Mamzer (red.), Instytucja „wczesnego państwa” w perspektywie wielości i różnorodności kultur, Poznań, IAiE PAN, s. 331-354.

Burchardt J. 1986, Dlaczego pogańscy Polanie w XI w. nie zniszczyli katedry gnieźnieńskiej?, „Literatura Ludowa" 1, s. 31-42.

Campbell J. 2007, Potęga mitu. Rozmowy Billa Moyersa z Josephem Campbellem, Kraków, Wydawnictwo Znak.

Cetwiński M. 2016, Kościół i blade widmo pogaństwa: średniowieczna historiografia o chrystianizacji ziem polskich, w: M. Rębkowski (red.), Kościoty w dobie chrystianizacji (Wolińskie Spotkania Mediewistyczne III), Szczecin, IAiE PAN, Katedra Archeologii US, s. 103-114.

Chudziak W. 2003, Wczesnośredniowieczna przestrzeń sakralna In culmine na Pomorzu Nadwiślańskim (Mons sancti Laurentii 1), Toruń, Wydawnictwo Naukowe UMK.

Danielewski M. 2019, Cuiavia Christiana. U progu chrześcijaństwa i Kościoła na Kujawach w X-XII wieku, Poznań, Wydawnictwo Naukowe UAM.

Delimata-Proch M. 2019, Rycheza. Królowa Polski (ok. 995-21 marca 1063). Studium historiograficzne, Kraków, Avalon.

Dobosz J. 2011, Chrzest Mieszka I w tradycji dziejopisarskiej, w: A. Różański (red.), Gemma Gemmarum. Studia dedykowane Profesor Hannie Kóčce-Krenz, Część pierwsza, Poznań, Wydawnictwo PTPN, s. 213-221.

Dowiat J. 1961a, Chrzest Polski, Warszawa, Wiedza Powszechna.

- 1961b, Metryka chrztu Mieszka I i jej geneza, Warszawa, PWN.

- 1962, Pogański obraz świata a przyczyny chrystianizacji Stowian, w: A. Gieysztor, M.H. Serejski, S. Trawkowski (red.), Wieki średnie. Medium aevum. Prace ofiarowane T. Manteufflowi w 60 rocznice urodzin, Warszawa, PWN, s. 79-86.

Dulinicz M. 2009, Wczesnośredniowieczny przełom w obrządku pogrzebowym na Mazowszu, w: S. Moździoch (red.), Stare i nowe w średniowieczu. Pomiędzy innowacja a tradycja, Wrocław, IAiE PAN, s. 379-399.

Gardeła L., Kajkowski K., Ratajczyk Z. 2019, Ostrogi zoomorficzne z Cieptego. Zachodniostowiański model kosmosu?, „Pomorania Antiqua” 28, s. 65-152.

Gieysztor A. 1960, Ideowe wartości kultury polskiej w w. X-XI. Przyjęcie chrześcijaństwa, „Kwartalnik Historyczny" 67/4, s. 922-938.

Górczak Z. 2000, Bunt Bezpryma jako poczatek tzw. reakcji pogańskiej w Polsce. Na marginesie koncepcji Gerarda Labudy, w: J. Strzelczyk, J. Dobosz J. (red.), Nihl superfluum esse. Studia z dziejów średniowiecza ofiarowane Profesor Jadwidze Krzyżaniakowej, Poznań, Instytut Historii UAM, s. $111-121$.

Guriewicz A. 1987, Problemy średniowiecznej kultury ludowej, Warszawa, PIW. 
Harris M. 985, Krowy, świnie, wojny i czarownice. Zagadki kultury, Warszawa, PIW.

Hensel W. 984, Skad przybyli Stowianie, Wrocław, Wydawnictwo Stronnictwa Demokratycznego.

Hilczer-Kurnatowska Z. 1982, Zaktadzina, w: G. Labuda, A. Gąsiorowski (red.), Stownik Starożytności Słowiańskich, t. 7, Warszawa, Zakład Narodowy im. Ossolińskich, s. 52-54.

Indycka E. 2000, Z badań nad cmentarzyskami gieckiego kompleksu osadniczego, „Studia Lednickie” 6, s. 69-89.

- 2008, Forma odlewnicza odkryta na stanowisku 4 w Gieczu, „Studia Lednickie” 9, s. 221-231.

Janiak T., Strzyżewski C. 1999, Z badań nad osadnictwem wczesnośredniowiecznym w regionie gnieźnieńskim, „Slavia Antiqua” 40, s. 31-54.

Janowski A. 2015, Groby komorowe w Europie Środkowo-Wschodniej. Problemy wybrane, Szczecin, IAiE PAN.

Jasienica P. 1961, Polska Piastów, Wrocław-Warszawa, PIW.

Kaczmarek J. 1998, Wczesnośredniowieczne przedmioty szkliwione zwiazane z magia z Kruszwicy, w: H. Kóčka-Krenz, W. Łosiński (red.), Kraje stowiańskie w wiekach średnich. Profanum i sacrum, Poznań, PTPN, s. 549-560.

Kajkowski K. 2015, The Dog in Pagan Beliefs of Early Medieval North-Western Slavs, w: L. Gardeła, A. Půlpánová-Reszczyńska (red.), Rituals in the Past (Analecta Archaeologia Ressoviensia 10) Rzeszów, Instytut Archeologii UR, Fundacja Rzeszowskiego Ośrodka Archeologicznego, s. 199-239.

- 2017, Mity, kult i rytuat. O duchowości nadbattyckich Stowian, Szczecin, Triglav.

- 2018, Symbolika wczesnośredniowiecznych depozytów szkieletów koni z ziem polskich w: S. Rosik, S. Jędrzejewska, K. Kollinger (red.), Hierofanie, wierzenia, obrzędy...Kultura symboliczna $w$ średniowieczu między pogaństwem a chrześcijaństwem (Materiały V Kongresu Mediewistów Polskich II), Rzeszów, Wydawnictwo Uniwersytetu Rzeszowskiego, s. 121-157.

- 2019, Obrzędowość religijna Pomorzan we wczesnym średniowieczu. Studium archeologiczne, Wrocław, Chronicon.

Kara M. 2006, Tron książęcy ad sanctam Mariam w Poznaniu w świetle ponownych dociekań analitycznych, „Slavia Antiqua” 47, s. 99-159.

- 2009, Najstarsze państwo Piastów - rezultat przełomu czy kontynuacji? Studium archeologiczne, Poznań, IAiE PAN.

- 2012, Stowo wstępne, w: M. Kara (red.), Wyniki analiz specjalistycznych materiatów wczesnośredniowiecznych z gnieźnieńskiego zespołu osadniczego, Gniezno, Muzeum Początków Państwa Polskiego w Gnieźnie, s. 7-13.

- 2013, Historiografia i archeologia polska o mechanizmach formowania się władztwa Piastów. Próba zestawienia ważniejszych pogladów, w: J. Banaszkiewicz, M. Kara, H. Mamzer (red.), Instytucja „wczesnego państwa” w perspektywie wielości i różnorodności kultur, Poznań, IAiE PAN, s. 303-316.

Kóčka-Krenz H. 2017, Archeologiczne ślady wczesnego chrześcijaństwa w Polsce, w: J. Dobosz, M. Matla, J. Strzelczyk (red.), Chrzest Mieszka I i chrystianizacja państwa Piastów, Poznań, Wydawnictwo Naukowe UAM, s. 111-123.

Krysztofiak T. 2016, Ośrodek grodowy w Gieczu w okresie przed- $i$ wczesnopaństwowym, w: M. Kara, T. Krysztofiak, A.M. Wyrwa (red.), Gród piastowski w Gieczu. Geneza - funkcja - kontekst, Poznan, Wydawnictwo PTPN, s. 115-154.

Krysztofiak T., Wyrwa A.M. (red.) 2016, Gród piastowski w Gieczu. Geneza-funkcja-kontekst, Poznań, Wydawnictwo PTPN.

Kurnatowska Z. 2000, Św. Wojciech a chrystianizacja Polski (w świetle źródet archeologicznych), w: A. Żaki (red.), Święty Wojciech i jego czasy. Materiały III Sympozjum Historyczno-Archeologicznego Polskiego Uniwersytetu na Obczyźnie Saint-Maurice, 12-13 kwietnia 1997 roku, Kraków, PAU, s. 111-128.

- 2003, Proces formowania się państwa gnieźnieńskiego, w: W. Chudziak (red.), Civitas Schinesghe cum pertinentiis, Torun, Wydawnictwo Naukowe UMK, s. 33-49.

- 2010, Budowanie państwa polskiego, w: W. Popek (red.), Santok. „Strażnica i klucz królestwa”. 30 lat Muzeum Grodu w Santoku. Wydawnictwo pokonferencyjne, 13 czerwca 2008 r., Gorzów Wielkopolski, Muzeum Lubuskie, s. 9-28. 
Kurnatowska Z., Kara M. 2010, Wczesnopiastowskie regnum - jak powstało i jaki miato charakter? Próba spojrzenia od strony źródet archeologicznych, „Slavia Antiqua” 51, s. 23-96.

Labuda G. 2008, Mieszko II. Król Polski (1025-1034). Czasy przełomu w dziejach państwa polskiego, Poznań, Wydawnictwo Poznańskie.

Makowiecki D. 2012, Wyniki badań archeozoologicznych szczątków kostnych z wykopalisk w Gnieźnie, stanowisko 22, w: M. Kara (red.), Wyniki analiz specjalistycznych materiałów wczesnośredniowiecznych z gnieźnieńskiego zespołu osadniczego, Gniezno, Muzeum Początków Państwa Polskiego w Gnieźnie, s. 153-252.

Małachowicz E. 2008, Architektoniczne ślady chrystianizacji Ślaska w IX-X w., „Nauka” 3, s. 161-176.

Matla M. 2017, Czeskie wpływy w życiu religijnym i piśmiennictwie państwa piastowskiego w X-XI wieku, Poznań, Instytut Historii UAM.

Michałowski R. 2008, Chrystianizacja monarchii piastowskiej w X-XI w, w: H. Manikowska, W. Brojer (red.), Animarum et cultura. Studia nad kultura religijna na ziemiach polskich $w$ średniowieczu, t. 1: Struktury kościelno-publiczne (Colloquia Mediaevalia Varsoviensia IV), Warszawa, Instytut Historii PAN, s. 11-49.

- 2016, Kontekst historyczny znaleziska w Bodzi, w: A. Buko (red.), Bodzia. Elitarny cmentarz z początków państwa polskiego, Warszawa, IAiE PAN, s. 33-39.

Miciak M. 2017, Cmentarzysko wczesnośredniowieczne w Gieczu, stan. 10. Wstępne wyniki badań, „Studia Lednickie" 16, s. 39-59.

Modzelewski K. 1987, Chtopi w monarchii wczesnopiastowskiej, Wrocław-Warszawa, Zakład Narodowy im. Ossolińskich.

Moździoch S. 2000, Ślask między Gnieznem a Praga, w: H. Samsonowicz red. Ziemie polskie w X wieku i ich znaczenie w ksztaltowaniu się nowej mapy Europy, Kraków, Universitas, s. 169-198.

Pauk M.R. 2017, „Quicquid partinebat ad Imperium”: Kościół w Polsce a Rzesza do połowy XII wieku, w: J. Dobosz, M. Matla, J. Strzelczyk (red.), Chrzest Mieszka I i chrystianizacja państwa Piastów, Poznań, Wydawnictwo Naukowe UAM, s. 249-280.

Pawlak E., Pawlak P. 2019, Przejawy życia duchowego mieszkańców grodu na stanowisku 2 w Dąbrówce, w: M. Szmyt, P. Pawlak (red.), Dwa grody nad Wirynka. Dąbrówka, stanowisko 1 i 2, woj. wielkopolskie (Bibliotheca Fontes Archaeologici Posnanienses 25), Poznań, Muzeum Archeologiczne w Poznaniu, s. 163-172.

Pollex A. 2011, Recepcja inhumacji u Stowian pótnocno-zachodnich, w: S. Cygan, M. Glinianowicz, P.N. Kotowicz (red.), ,In silvis, campis ... et urbe”. Średniowieczny obrzadek pogrzebowy na pograniczu polsko-ruskim, Rzeszów-Sanok, Fundacja Rzeszowskiego Ośrodka Archeologicznego, s. 483-509.

Potkański K. 1924, Wiadomości Dlugosza o polskiej mitologii, w: F. Bujak (red.), Pisma pośmiertne Karola Potkańskiego, t. 2, Poznań, Wydawnictwo PTPN, s. 319-379.

Rębkowski M. 2006, Kilka uwag w sprawie genezy orientacji pochówków szkieletowych we wczesnym średniowieczu, w: M. Dworaczyk, A.B. Kowalska, S. Moździoch, M. Rębkowski M. (red.), Świat Stowian wczesnego średniowiecza, Szczecin-Wrocław, IAiE PAN, s. 515-520.

- 2007, Chrystianizacja Pomorza Zachodniego. Studium archeologiczne, Szczecin, IAiE PAN.

Rodzińska-Chorąży T. 2000, Co nam mówi architektura murowana?, w: H. Samsonowicz H. (red.), Ziemie polskie w X wieku i ich znaczenie w ksztaltowaniu się nowej mapy Europy, Kraków, Universitas, s. 361-387.

Rowell S.C. 2017, Pogańskie imperium. Litewska dominacja w Europie Środkowo-Wschodniej, 1295-1345, Oświęcim, Wydawnictwo Napoleon V.

Sawicki T. 1999, Z badań nad przemianami topografii i funkcji grodu książęcego na Górze Lecha w Gnieźnie, „Slavia Antiqua” 40, s. 9-29.

- 2017, Przedchrześcijańska konstrukcja kamienna na Górze Lecha w Gnieźnie, w: A. Różański (red.), Gemma Gemmarum. Studia dedykowane Profesor Hannie Kóčce-Krenz. Część pierwsza, Poznań, Wydawnictwo PTPN, s. 641-668.

Sikorski D.A. 2016, Chrzest Polski i poczatki Kościoła w Polsce (do pierwszej połowy XI wieku), w: Chrzest - św. Wojciech - Polska. Dziedzictwo średniowiecznego Gniezna (Katalog wystawy), Gniezno, Muzeum Początków Państwa Polskiego w Gnieźnie, s. 25-38. 
Słupecki L.P. 1994, Slavonic Pagan Sanctuaries, Warsaw, IAiE PAN.

- 2002, Pagan Religion and Cultural Landscape of Northwestern Slavs in the Early Middle Ages, "Siedlungforschung. Archäologie - Geschichte - Geographie" 20, s. 25-40.

Strzelczyk J. 2001, The Church and Christianity about the Year 1000 (The Missionary Aspect), w: P. Urbańczyk (red.), Europe around the Year 1000, Warsaw, DiG, s. 41-67.

- 2012, Koronacje pierwszych Piastów, w: D. Pasiciel, D., Struniak (red.), Gniezno - miasto królów, Gniezno, Muzeum Początków Państwa Polskiego w Gnieźnie, s. 13-28.

- 2016, Chrzest Polski - zmiana cywilizacyjna i polityczna, w: W. Graczyk, J.M. Marszalka, Z. Fałkowski, L. Zyner (red.), Kościót, kultura, polityka w państwie pierwszych Piastów, Warszawa-Ciechanów, Uniwersytet Kardynała Stefana Wyszyńskiego w Warszawie, Państwowa Wyższa Szkoła Zawodowa w Ciechanowie, s. 13-25.

- 2017, Powikłane koleje chrystianizacji Stowiańszczyzny Połabskiej, w: W. Dzieduszycki, J. Wrzesiński (red.), Chrzest - przemiany religijne, kulturowe i sepulkralne (Funeralia Lednickie 19), Poznan, SNAP, s. 61-73.

Szajnocha K. 1859, Bolestaw Chrobry i odrodzenie się Polski za Władysława Łokietka. Dwa opowiadania historyczne, Lwów, Nakładem Karola Wilda.

Śliwiński B. 2012, Bezprym. Pierworodny syn pierwszego króla Polski (986 - zima/wiosna 1032), Kraków, Avalon.

Tabaka A. 2013, Monety i biżuteria z Ostrowa Lednickiego i okolicy. Analiza i historyczna kwerenda znalezisk, w: A. Tabaka, A.M. Wyrwa (red.), Monety i biżuteria z Ostrowa Lednickiego i okolicy, Lednica, Muzeum Pierwszych Piastów na Lednicy.

Tyszkiewicz J. 2016, Mazowsze w państwie Piastów do końca XII wieku, w: W. Graczyk, J.M. Marszalska, W. Fałkowski, L. Zygner (red.), Kościót, kultura, polityka w państwie pierwszych Piastów, Warszawa-Ciechanów, Uniwersytet Kardynała Stefana Wyszyńskiego w Warszawie, Państwowa Wyższa Szkoła Zawodowa w Ciechanowie, s. 203-213.

Urbańczyk P. 2015, Zanim Polska została Polska, Toruń, Wydawnictwo Naukowe UMK.

- 2016, Co się stało w 966 roku?, Poznań, Zysk i S-ka.

- 2017, Bolestaw Chrobry - lew ryczacy, Torun, Wydawnictwo Naukowe UMK.

Węcowski P. 2014, Początki Polski w pamięci historycznej późnego średniowiecza, Kraków, Towarzystwo Naukowe Societas Vistulana.

Wiszewski P. 2008, Domus Bolezlai. W poszukiwaniu tradycji dynastycznej Piastów (do około 1138 roku), Wrocław, Wydawnictwo UWr.

Wołoszyn M. 2017, Bizantyński i taciński model chrystianizacji w świetle danych archeologicznych uwagi dyskusyjne, w: S. Cygan, M. Glinianowicz, P.N. Kotowicz (red.), ,In silvis, campis... et urbe”. Średniowieczny obrzadek pogrzebowy na pograniczu polsko-ruskim, Rzeszów-Sanok, Fundacja Rzeszowskiego Ośrodka Archeologicznego, s. 243-255.

Wyrwa A.M. 2016, W poszukiwaniu zaginionej świetności. Spojrzenie „starożytników” i pierwsze naukowe refleksje nad piastowskim grodem w Gieczu (1810-1924), w: M. Kara, T. Krysztofiak, A.M. Wyrwa, Gród piastowski w Gieczu. Geneza - funkcja - kontekst, Poznań, Wydawnictwo PTPN, s. 27-57.

- 2018, Historia odkrycia szyszaka znalezionego „,w bagnie” koło Giecza i jego miejsce w kulturze, w: P. Sankiewicz, A.M. Wyrwa (red.), Broń drzewcowa i uzbrojenie ochronne z Ostrowa Lednickiego, Giecz i Grzybowa (Biblioteka Studiów Lednickich. Fontes 1), Lednica, Muzeum Pierwszych Piastów na Lednicy, s. 89-107.

Zoll-Adamikowa H. 1998, Zum Beginn der Körperbestattungen bei den Westslawen, w: M. Müller-Wille (red.), Rom und Byzanz im Norden. Mission und Glaubenswechsel im Ostseeraum während des 8. - 14. Jahrhunderts. 2. Internationale Fachkonferenz der Deutschen Forschungsgemeinschaft in Verbindung mit der Akademie der Wissenschaften und der Literatur Mainz, Kiel, 18-25 September 1994, Mainz-Stuttgart, Akademie der Wissenschaften und der Literatur, Franz Steiner Verlag, s. 227-238. 